\title{
The Effect of Computerized Tax Services in Improving Tax Performance Moderated by Governance
}

\author{
Sanaa Nazami MASWADEH ${ }^{1}$, Tariq Samih HANANDEH ${ }^{2}$
}

Received: September 10, 2020 Revised: November 02, 2020 Accepted: November 16, 2020

\begin{abstract}
This study aims to evaluate the effect of computerized tax services in improving tax performance by moderating governance principles in Jordanian tax income departments. The study is based on a questionnaire distributed to income tax auditors, who were chosen by the simple random sampling method, so that 170 questionnaires were subjected to statistical analysis. The study models were formulated in the form of simple and multiple regression equations to test the hypotheses of the study, in addition to relying on One Sample T-test to calculate the mean of questionnaire answers. The most prominent research results is that the application of tax governance principles through the provision of computerized tax services is reflected in the increase in confidence between taxpayers and income tax departments, the efficiency of tax performance, and tax proceeds. Also, the study pointed out the importance of the income tax departments to prepare strategic plans regarding the development and the follow-up of modern technologies related to computerized tax services. It especially regards linking and collecting tax from taxpayers such as via electronic tax payment and collection system, in order to ensure the speed of completion, accuracy of calculation, and raising the efficiency of tax performance.
\end{abstract}

Keywords: Computerized Tax Services, Income Tax Auditor, Jordanian Tax Income Departments, Governance

JEL Classification Code: G38, H20, M14, M15

\section{Introduction}

The Income Tax Department in Jordan launched an e-government program. It was considered the first e-government program to be implemented in government institutions and departments in the Hashemite Kingdom of Jordan, as it aimed to provide high-quality services, which would reduce time and effort for the taxpayer to enable him/ her to obtain the service without attend to the department's offices, whether inside or outside Jordan and over the course of the clock and the length of the year. The use of

${ }^{1}$ First Author and Corresponding Author. Professor, Accounting Department, School of Business, Jadara University, Irbid, Jordan [Postal Address: P.O. Box 733, Irbid 21110, Jordan] Email: mmsana59@gmail.com

${ }^{2}$ Doctorate Student, Economics and Muamalat Administration, University Sains Islam Malaysia. Irbid, Jordan.

Email: tarek.hanandeh@gmail.com

(C) Copyright: The Author(s)

This is an Open Access article distributed under the terms of the Creative Commons Attribution Non-Commercial License (https://creativecommons.org/licenses/by-nc/4.0/) which permits unrestricted non-commercial use, distribution, and reproduction in any medium, provided the original work is properly cited. the electronic government program reduced the burden of paper and stationery use in transactions on taxpayers and the department, and facilitated retrieval of file information without the need to refer to paper files. This is done by linking the electronic government program to the electronic archiving system prepared by the department to save its documents in databases prepared for this purpose (Income Tax Department website, 2019).

Among the most prominent services covered by the electronic government's income tax program are: the filing service of income tax statement from tax payer, as well as the service of obtaining a statement of estimated tax years, the amount of the balance due, paid and installments, and many tax information of interest to taxpayers, as well as the possibility of electronic payment of tax dues. There is no need to review the fund at the department or banks, with the ability to obtain the payment voucher online, as well as access to any information needed by the taxpayer with regard to how the tax is calculated and legal supporter on immediate assistance online-help. All that is new can be followed up on the department's website, so that the site is updated with all that happens to the laws, legislations and procedures necessary to calculate and pay the tax immediately, in both 
Arabic and English language (Income Tax Department website, 2019).

In the era of globalization, the principles of governance have appeared to impose themselves in the work of companies and international and governmental organizations due to the role it plays in financial control, which is based on rules and foundations that ensure the detection of cases of manipulation and corruption and in order to ensure the integrity of business results through transparency in disclosure. Since the tax is a cost imposed on corporate profits, the management of these companies and taxpayers resort to using a set of practices to influence the profits shown in the financial statements to avoid paying the tax. For this reason, it was necessary to consider studying the ability and feasibility of governance principles and their role in strengthening the supervisory role over computerized tax services, which the state sought to establish to improve the efficiency of tax performance in income tax departments by providing performance standards that ensure the detection of cases of corruption and mismanagement, whether its application was in the private sector or the public sector. Especially, income tax plays an important role in the state's financial system as the main source of financing the state's budget, through which growth is stimulated and economic stability is achieved, with the aim of growing investment and the state's national income.

\subsection{Problem of the Study}

Previous studies (Joudih, 2016; Qublan, 2014; Khanfari \& Yazid, 2019; Shaker, 2017) showed the weakness of the tax administration is that it still relies on inappropriate old manual methods, which led to the implementation of many measures to slow and delay the collection of tax and write it off by statute of limitations. Also, the use of manual tax examination has led to the difficulty of inventorying and controlling the tax community, lack of coordination between different departments and systems such as the payment and tax collection system, and the failure to link the Income tax department with other official bodies such as the Ministry of Commerce and Industry and others, which resulted in a negative impact on tax performance and tax proceeds. This led the Jordanian government to develop its tax system and rely on computerized tax services to complete tax examination procedures

Therefore, the study problem was identified in assessing the impact of computerized tax services related to issuing a website to complete taxpayers' transactions, starting with submitting the tax declaration and ending with paying the income tax due. It also focuses on improving tax performance under the implementation of governance principles by imposing a system of control and follow-up on the tax services provided, disclosure with credibility and transparency. A lack of commitment to governance principles increases the opportunity for stakeholders to manipulate and be lax in providing tax services to those charged with equality and fairness, and thus slackening the performance of income tax departments and reviewing the state's tax revenue and the negative effects that have on the national economy as a whole. Therefore, this study seeks to answer the following main question: What is the impact of computerized tax services on improving tax performance in the light of the implementation of governance principles in Jordanian tax income departments?

\subsection{Study Contribution}

The contribution of the study stems from the importance of the principles of governance and what they represent in terms of the control system and for the purpose of supervising and controlling the performance of public institutions, including income tax departments in light of the Jordanian environment. It examines achieving credibility in the information provided by taxpayers affected by computerized tax services, which is reflected in the efficiency of tax performance.

An evaluation of computerized tax services helps income tax departments improve their performance by developing procedures and computerized tax services to reduce time, effort and cost, hence increasing tax proceeds. In addition to assisting in identifying deficiencies in computerized tax services, it prompts them to address these aspects in a way that achieves the desired objectives. Assisting the official authorities, including the Ministry of Finance, which seek to automate Jordanian computerized tax information systems and ensure that this automation is moving in the direction of enhancing the confidence of taxpayers in the income tax department. It does so by identifying mechanisms that seek to improve the effectiveness of computerized tax services in the transition phase to the electronic government, and their impact on increasing tax revenues and its impact on economic growth in Jordan, the well-being of citizens and attracting local and foreign investments to the Kingdom.

Finally, this study contributes to being a future reference for future research with the aim of developing and improving tax collection procedures in Jordan and other developing countries. It is hoped that the results and recommendations of this study will benefit scholars in carrying out other studies related to the subject.

\section{Literature Review}

Since we live in a time of globalization and the technological developments that accompany this era, it was necessary for the public sector institutions to keep pace with this development by employing the latest technological 
means in carrying out their tasks. Hence, it was necessary for the Income Tax Department to develop its tax systems to keep pace with the technological developments, and thus to move to computerized tax systems instead of relying on the traditional manual systems.

All this pushed the Jordanian Income Tax Department to keep pace with this development by launching an e-government services program that provided many services, the most prominent of which were: presenting the income tax statement electronically with a mechanism for calculating the tax immediately through the computerized system and pay the tax due electronically so that it is sufficient to obtain the electronic payment voucher available on the electronic department's website by selecting the electronic payment icon E-Fawateercom.com without the need of a presence in the financial department's fund or banks. Obtaining a tax statement and tax certificate number in addition to obtaining all information related to the tax statement for the estimated tax years are subject to objection and appeal, balances due, installment paid and others. Several other services are also provided, including inquire about refunds, objection (submission and response to an objection), postponement tax payment, requests to get tax exemptions and others (Income Tax Department website, 2019).

Governance is defined as "a set of foundations, principles, executive rules and organizational procedures that enhance the performance control of the tax system by defining the roles of the parties with an independent relationship" (Al-Momaniand \& Al-Abini, 2018). Qaidum and Twaitiyeh,(2019) defined it as a set of rules and procedures operated by the tax administration, to ensure the continuation of the operational process and its advancement, and to increase confidence between taxpayers and income tax administrations, to achieve justice, provide transparency, activate oversight and accountability for all its employees, which is reflected in increased confidence in the tax system and increased state tax revenues.

Shaker's (2017) study concluded that the tax charging procedures followed by the Iraqi General Tax Authority are still suffering from a lack of modern technologies given the importance of modern technologies with regard to linking and collecting tax from taxpayers such as the electronic tax payment and collection system. Increasing the efficiency of the tax charging procedures is an objective of the Public Tax Authority in Iraq.

Joudih (2016) found that the introduction and application of information and communication technology in the tax system in Jordan helped achieve the objectives of the tax departments, including: increasing tax collections, increasing voluntary commitment to tax laws, and working to attract investments, and achieve tax justice as much as possible. Qublan (2014) concluded that there is a weakness in the traditional procedures applied in the Jordanian Income and
Sales Tax Department to reduce tax evasion, while Jaradat (2013) found a positive impact of submitting tax statement and its effect on increasing tax collection.

Khanfari and Yazid (2019) show the weakness of the Algerian tax administration, which relies on inappropriate old manual methods and does not coordinate between different administrations, which had a negative impact on the tax proceeds. Al-Hamza (2018) found that the use of the electronic tax examination in Algeria led to the implementation of many tax examination procedures with high accuracy and as quickly as possible, which resulted in no delay in the process of assessing and collecting the tax, not writing it off with the statute of limitations, and the ease of inventory and control of the tax community. AlTaher and Maamari (2019) showed that the application of governance principles increases the dialogue mechanism between taxpayers and managers of tax administrations, and increases their ability to inform taxpayers of the amount of tax at a specified time through the communication channels approved by the tax office, which is reflected in the increased confidence between taxpayers and tax department and increases tax proceeds from them.

The study of Al-Momani and Al-Abini (2018) concluded that there is a positive effect of tax governance, "tax control", on tax revenues in the Income and Sales Tax Department in Jordan, and the need to expand the use of digital technology and the technological link with all departments and control centers for the transfer of information.

Abdulkafi's study (2018) concluded that the application of the governance system in the administration of the Libyan Tax Authority has a positive impact on the procedures of tax collection methods through the inventory and registration of taxpayers and their follow-up, which is reflected in the increase in tax revenues. Ameen's study (2017) indicated that audit taxation of income tax departments contributes significantly to increasing the Algerian tax collections, by collecting the tax debt that taxpayers evade, in addition to the interest of tax governance in activating the penalties for tax evasion. Bakr (2015) concluded that the application of tax governance leads to adding confidence and credibility in the financial reports submitted to the Income and Sales Tax Department by taxpayers in Jordan. It led to reducing the cases of tax evasion and, thus, the possibility of determining the tax base fairly.

Karimi et al. (2017) showed that information technology systems have led to the development of related processes in internal control systems, which in turn enhanced the effectiveness and efficiency of the performance of tax department's employees in Kenya. Monica et al. (2017) indicated that the efficiency of the electronic tax system greatly contributes to the effectiveness of tax collection in Kenya. Allahverdi et al. (2017) showed that the application of the electronic tax system has a positive impact on tax 
revenues and reduces the costs of tax collection in Turkey. Olatunji and Ayodele (2017) indicated that implementing IT enhances tax performance in Nigeria's income tax departments.

Nguyen et al. (2020) studied the factors affecting corporate income tax non-compliance of enterprises in accordance with the current situation of Vietnamese tax administration. The study found the tax non-compliance was considered as a violation of Vietnamese tax laws by enterprises declaring an insufficient amount of corporate income tax payable to the State budget. Kwak and Park, (2020) examines the effect of the audit offer and simultaneous tax services from auditors on the firm value of clients; the study used the samples of auditors' tax services selected from firms listed on the securities markets of Korea. The major findings show that a tax service has a positive effect on the firm value. The results showed investors could invest in those firms where the auditor could increase the firm value through audit and tax services. Salehi et al. (2019) investigate the relationship between tax avoidance and firm risk in an emerging market, Iran. The results showed, there is no significant relationship between tax avoidance and future tax rate volatility. The findings proved that lower effective tax rates are positively correlated with volatility of future stock price.

After reviewing the previous studies and the theoretical literature on the subject, the following hypotheses were developed:

H1: There is no significant difference computerized tax services make in improving tax performance, attributable to governance at a significant level $(\alpha \leq 0.05)$.

$\mathrm{H} 2$ : There is no significant effect of computerized tax services on improving tax performance at a significant level $(\alpha \leq 0.05)$.

H3: There is no significant effect of computerized tax services on improving tax performance attributable to governance at a significant level $(\alpha \leq 0.05)$.

\section{Methodology}

This part includes an analytical description of the study methodology, where it begins by addressing the population and sample of the study, the instruments of the study used to collect data, and the statistical methods used in analyzing the study data and testing its hypotheses.

\subsection{Study Population and Sample}

The study population consists of all the income tax department auditors in Jordan, whose number totals 300 according to the location (Income Tax Department, 2019). Out of the income tax auditors selected by a simple random sampling method, 184 questionnaires were completed and returned, of which 170 were valid for statistical analysis, so 14 questionnaires were excluded due to lack of answers or containing the same answer for all paragraphs of the questionnaire.

\subsection{The Instrument of the Study}

The study instrument, the questionnaire, was designed by reviewing the theoretical literature and benefiting from previous studies. The study tool consisted of two parts: demographic variables, including demographic information such as age, academic qualification, job title, and number of years of experience, professional certificates, and participation in training courses in the tax field and in the field of computerized information systems. The second part included 10 special statements on computerized tax services to improve tax performance, and 15 statements related to governance as an intermediary variable between computerized tax services and tax performance. And 12 items related to the dependent variable, which is tax performance.

A 5-point Likert scale was used to determine the degree of consent by the sample members to each statement of the study instrument, and to convert them into quantitative data that can be measured statistically; '5' Strong agree, '4' Agree, ' 3 ' Moderately agree, ' 2 ' Disagree, ' 1 ' Strongly disagree.

\subsection{Statistical Methods Used in Data Analysis}

The Statistical Package for Social Sciences SPSS was used in the analysis of the collected data. Several statistical methods were used to achieve the objectives of the study and test the hypotheses, including the use of distribution frequency, reliability testing and the use of the Cronbach's Alpha test to verify the amount of internal consistency of the study sample responses to the questionnaire statements. The One Sample t-test was used to compare the arithmetic means of the answers of the study sample responses with the value of a weighted arithmetic mean (the test value), and since the study's measurement was a 5-point Likert scale, the weighted average value with which the comparison was made is 3 . If the significance is ( $\mathrm{Sig} \leq 5 \%$ ), then there are statistically significant differences between the mean answers from the test value (3), and if the significance is ( $\mathrm{Sig}>5 \%$ ), then, there are no statistically significant differences between the mean answers from test value of (3). A multi-collinearity test was performed using the variance inflation factor-VIF for each of the independent variables. To test the absence of data from the problem of auto-correlation between the estimated error limits in the regression model, the Durbin-Watson test was relied on, and to test the study hypotheses, the simple and multiple linear regression method was used.

The study models were formulated in the form of regression equations to test tax governance as a moderating variable, and their effect on computerized tax services on tax performance, which was as follows? 
$\operatorname{Tax} P=\beta_{0}+\beta_{1}^{*} \operatorname{Tax} C S+\varepsilon$

$\operatorname{Tax} P=\beta_{0}+\beta_{1}{ }^{*} \operatorname{Tax} C S+\beta_{2}^{*} G O+\varepsilon$

Which is:

Tax $P=$ Tax Performance

Tax $C S=$ Computerized Tax Services

$G O=$ Governance

$\varepsilon=$ Estimated error of equation.

$\beta_{0}=$ The equation constant

$\beta_{1}, \beta_{2}, \beta_{3}=$ The regression coefficients of the independent and control variables.

\section{Results}

\subsection{Statistical Analysis and Hypothesis Testing of the Study}

To ensure the reliability of the study instrument (the questionnaire), the internal reliability coefficient (Cronbach's Alpha) was calculated as follows:

Table 1 shows that the reliability coefficient for the whole questionnaire reached (0.96), which is a high coefficient indicating the stability and consistency of the study answers. The results are high and statistically acceptable as per Sekaran and Bougie (2013), who indicated that the acceptance rate of the Cronbach's Alpha was (0.60).

After calculating the distribution frequency, and the percentages, of the frequencies associated with the characteristics of the study sample respondents, it was observed that the majority was mature and of young ages, between $30 \mathrm{a}$ and 35 years, accounting for it $44 \%$ of the sample. It was found that most of the respondents $(75 \%)$ had a bachelor's degree, and $78 \%$ had the job title of tax auditor. With regard to the number of years of practical experience, it was found that $84 \%$ ) had more than five years of experience. It was found that the most prominent recurrence of the variable of professional certificates is the holders of the (CMA) certificate, at a rate of $14 \%$, especially given the CMA certificate is one of the most attractive professional

Table 1: Internal reliability of study instrument

\begin{tabular}{|l|c|c|}
\hline variables & \# of Items & $\begin{array}{c}\text { Cronbach's } \\
\text { Alpha }\end{array}$ \\
\hline $\begin{array}{l}\text { Computerized Tax } \\
\text { Services }\end{array}$ & 10 & 0.88 \\
\hline Governance & 15 & 0.95 \\
\hline Tax Performance & 12 & 0.91 \\
\hline whole Instrument & 37 & 0.96 \\
\hline
\end{tabular}

certificates among the youth in Jordan. It was found that all the respondents participated in training courses related to computerized information systems, accounting qualification courses in tax and accounting auditing, income tax law, sales tax and other training courses that helped the income tax department auditors to keep pace with the practical reality and developments and new developments. By reviewing the demographic characteristics of the study sample, it can be inferred that the respondents have sufficient scientific and practical experience and knowledge in the field of tax, which qualifies them to answer the statements of the questionnaire.

To test the relevancy of the study data for a regression test, the following tests were used, which are shown in Table 2:

One of the conditions of validity of the General Linear Model (GLM) is that the values of the observations follow a normal distribution, and based on the Central Limit Theory, which states that it is possible to assume that the normal distribution condition is met for large samples $(n>30)$, we can assuming the normal distribution of the data, given that the number of respondents in the study is 170 (Dinov et al., 2008).

By referring to Table 2, it was found that there is no multicollinearity between the independent variables, as the value of the variable inflation factor (VIF)) was less than 5 for each of the independent variables, thus accepting the level of variance in each of the independent variables in model 1 and model 2 of the study (Luo et al., 2007).

The Durbin-Watson (D-W) test was relied on to test autocorrelation problem between the estimated errors in the two regression models, and it became clear from Table 2 that the D-W test value was between zero and 4 and close to the value 2 , which indicates that the study data are free from the problem of auto-correlation (Chatfield, 2005).

\subsection{Statistical Results of One Sample T-Test}

To identify the importance of computerized tax services, tax governance and tax performance in Jordanian tax income departments, the results of the analysis of the opinions of the study sample respondents according to the One Sample t- test were presented, and the test results are shown in Table 3:

Table 2: Relevance of Study Data to Regression Analysis

\begin{tabular}{|l|c|c|}
\hline Variables & Model 1 & Model 2 \\
\hline VIF- Computerized Tax Services & 1 & 1.63 \\
\hline VIF- Governance & & 1.63 \\
\hline D.W test & 2.429 & 2.332 \\
\hline No of Observation & 170 & 170 \\
\hline
\end{tabular}

Source: Result Output from SPPS Statics Analysis 
Table 3: One Sample T-Test Related to the paragraphs of computerized tax services, and governance, and tax performance

\begin{tabular}{|l|c|c|c|c|}
\hline Items & mean & $\begin{array}{c}\text { Std } \\
\text { Deviation }\end{array}$ & T - Value & Sig \\
\hline $\begin{array}{l}\text { The arithmetic mean of the total Paragraphs related to the elements } \\
\text { of Computerized Tax Services }\end{array}$ & 3.84 & 0.598 & 18.407 & 0.00 \\
\hline $\begin{array}{l}\text { The arithmetic mean of the total Paragraphs related to the elements } \\
\text { of Governance }\end{array}$ & 3.95 & 0.652 & 19.012 & 0.00 \\
\hline $\begin{array}{l}\text { The arithmetic mean of the total Paragraphs related to the elements } \\
\text { of Tax Performance }\end{array}$ & 3.93 & 0.593 & 20.520 & 0.00 \\
\hline
\end{tabular}

Source: Result Output from SPPS Statics Analysis

Table 4: Moderating Tax Governance on the Effect of Computerized Tax Services on Tax Performance

\begin{tabular}{|c|c|c|}
\hline \multirow{2}{*}{ Variables } & $\operatorname{Tax} P=\beta 0+\beta 1^{*} \operatorname{Tax} C S+\varepsilon$ & $\operatorname{Tax} P=\beta 0+\beta 1^{*} \operatorname{Tax} C S+\beta 2 \operatorname{Tax} G+\varepsilon$ \\
\hline & Model 1 & Model 2 \\
\hline constant & 1.097 & 0.396 \\
\hline Computerized Tax Services (CTS) & 0.738 & 0.384 \\
\hline Governance (GO) & & 0.521 \\
\hline Sig- CTS & 0.000 & 0.000 \\
\hline Sig- TG & & 0.000 \\
\hline $\mathrm{R} 2$ & 0.553 & 0.754 \\
\hline Adjust R2 & 0.550 & 0.751 \\
\hline$(\mathrm{F})$ & 207.697 & 256.496 \\
\hline F - Sig & 0.000 & 0.000 \\
\hline No of Observation & 170 & 170 \\
\hline
\end{tabular}

Table 3 shows that all the statements of the questionnaire related to computerized tax services and governance in addition to tax performance obtained an arithmetic mean that exceeds the test average of 3 , with a statistical significance of $\mathrm{a} \leq 0.05$, where the mean of both of them are $3.84,3.95$, 3.93 , respectively. In statistical terms $(0.00)$, it reinforces the role and importance of computerized tax services and tax governance in influencing tax performance from the viewpoint of Jordan's income tax auditors.

\subsection{Hypothesis Testing}

In order to test the two study models related to the effect of electronic tax services on tax performance by moderating governance variable, we relied on a simple and multiple regression models, the results of which appeared in Table 4.

The researcher used the regression model to test the effect of computerized tax services on tax performance by moderating tax governance; as is clear in Table 4, the calculated value of $\mathrm{F}$ for model 1 and model 2 reached 207.697 and (256.496, respectively. The value of the probability
Sig. F for both of them was (0.000), which is less than the statistical significance $a \leq 0.05$, indicating that the first and second study models are acceptable statistically, and have statistical ability to explain the variance in tax performance. It was shown in model 1 the value of the explanatory coefficient was $\mathrm{R}^{2}=0.553$, meaning that computerized tax services accounted for $55.3 \%$ of the variance that occurred in tax performance for Jordanian tax income departments.

The results of Table 4, and with reference to model 2, indicate that the value of the explanatory coefficient reached $\mathrm{R}^{2}=0.754$, which means that computerized tax services moderated by governance explained an amount of $75.4 \%$ of the variance in tax performance. That is an increase in the explanatory coefficient $\mathrm{R}^{2}$ that amounted to $20.1 \%$, compared with model 1, leading to accept the alternative hypothesis, which states "There is significant difference for computerized tax services in improving tax performance, attributable to governance at a significant level $\alpha \leq 0.05$ ", and this result is in agreement with Al-Hamza (2018), Shaker (2017), Al-Taher and Maamari(2019) and Bakr (2015), and Karimi, et al. (2017), who found the existence of 
a difference between electronic tax services and manual tax services on tax performance in light of the implementation of governance principles.

Referring to Table 4, the value of the computerized tax services regression coefficient was 0.738 , while the value of the significance was $\mathrm{Sig}=0.000$ in model 1, which confirms the existence of a significant effect of computerized tax services on tax performance at a significant level of $\alpha \leq$ 0.05. Therefore, the alternative hypothesis is accepted, which states: "There is significant effect of computerized tax services in improving tax performance at a significant level $\alpha \leq 0.05$ ". This result was in line with Jaradat (2013), Joudih (2016), Monica et al. (2017), and (Olatunji \& Ayodele, 2017). These studies have shown that there is a positive significant effect of electronic tax services on tax performance.

It was found from Table 4 and with reference to model 2 that the value of the regression coefficient for computerized tax services and tax governance amounted to 0.384 and 0.521 respectively, and the significance value for both of them reached Sig $=0.000$, which confirms the existence of a significant positive effect of both computerized tax services and governance on tax performance at a significant level $\alpha \leq 0.05$. Thus, the alternative hypothesis is accepted, which states: "There is significant effect of computerized tax services in improving tax performance attributable to governance at a significant level $\alpha \leq 0.05$ ". This result was in agreement with Khanfari and Yazid (2019), Al-Momani and Al-Abini (2018), Abdulkafi (2018), Ameen (2017), and Allahverdi et al. (2017) who confirmed the existence of an effect of electronic tax services attributable on the governance on tax performance.

\section{Conclusion}

Through its provision of computerized tax services, Jordanian tax income departments seek to collect data, operate it, produce information and submit it to taxpayers in a timely manner in order to assist them in improving the tax-charging procedures and reducing the financial burdens, whether on the state or on taxpayers. This, in order to increase the efficiency of tax performance and the availability of supportive tax resources and contribute to covering public sector expenditures.

The study found that the income tax departments provide computerized tax services, including the website containing understandable and clear instructions for taxpayers on how to fill out the tax statement and not having to depend on the Income Tax Department for obtaining the information necessary to file the tax statement, and obtaining the tax statement and tax certificate number for taxpayers, which led to improved tax performance. This is reflected in the accuracy and speed of submitting the tax statement and tax collection, and the ease to inventory taxpayers and follow-up them.
The study concluded that increasing the effectiveness of the performance of Income Tax Departments is affected by the development of electronic computing services, the software used in information technology, the provision of useful accounting information, and the provision of qualitative human competencies, in light of applying governance principles through expansion using digital technology and connectivity with all the public departments and control centers.

The study showed that implementing governance principles by applying computerized tax services provides the necessary information with credibility in a timely manner, in addition to treat each taxpayers category in a fair manner, and increases its ability to inform taxpayers of the amount of the tax at the specified time through the communication channels approved by the Tax Department. This is reflected in the increased confidence between taxpayers and the Income Tax Department, the efficiency of tax performance and tax collections.

The study recommended the necessity for the Income Tax Departments in Jordan to develop their employees and subject them to training permanently to be contemporary with the most important electronic developments, which are constantly changing, in order to possess the necessary skill and knowledge of electronic computing methods in various fields.

In addition, the responsibility of the authorities in the Income Tax Departments is to prepare strategic plans regarding the development and follow-up of modern technologies of computerized tax services, especially with regard to linking and collecting taxes from taxpayers such as the electronic tax payment and collection system, in order to ensure the speed and accuracy of completion and calculation tax, and raising the efficiency of tax performance.

The study recommends the necessity of offering incentives for users of electronic systems, to encourage taxpayers to fully switch to using electronic services and not rely on the inappropriate manual methods due to their negative impact on the tax proceeds.

Finally, the study recommended Income Tax Departments to adhere to laws and directives that define the duties of officials, and increase the legal penalties on tax evaders.

The study was limited to a questionnaire that was distributed to the auditors of the Jordanian Income Tax Department. Therefore, it is difficult to generalize the results to developed countries due to the difference in the level of technological development among them. The researchers were not able to distribute the questionnaire to the recipient of the tax service (taxpayers), so one of the proposed studies in the future is to examine the effect of computerized tax services from the point of view of taxpayers receiving these services. 


\section{References}

Abdulkafi, A. S. (2018). The effect of implementing the governance system on improving tax revenue collection procedures. Shuaa Journal of Economic Studies, 2(2), 176-191. https://www.asjp. cerist.dz/en/article/76945

Al-Hamza, A. (2018). Electronic tax examination as a tool to activate the work of the tax administration: Towards a model for the electronic information system in the tax administration in Algeria. Journal of Tax Studies, 7(12), 87-109. https://search. emarefa.net/detail/BIM-889465

Allahverdi, M., Algoz, A., \& Ortakarpuz, M. (2017). The Effect of E-taxation System on Tax Revenues and Costs: Turkey Case. Working Paper. Available at: https://www.researchgate.net/ publication/320183619

Al-Momani, S. N., \&, Al-Abini, M. M. (2018). Tax governance and tax revenues. Journal of Development and Applied Economics, 36(3), 190-205. http://dspace.univ-msila.dz:8080//xmlui/ handle/123456789/7484

Al-Taher, T., \& Maamari, R. (2019). The role of tax governance principles in activating tax inspection mechanisms. Case study of the tax directorate in Umm El Bouaghiwilaya. Journal of Finance and Corporate Governance, 3(2), 42-75. https://www. asjp.cerist.dz/en/article/112086

Ameen, R. (2017). The role of in-depth tax investigation in activating tax governance to combat tax evasion. Roalktissadia Review, 7(12), 485-503. http://dspace.univ-eloued.dz/handle/12 $3456789 / 5814$

Bakr, A. (2015). Tax governance and its impact on reducing tax evasion. Journal of Tax Studies, 4(1), 07-36. https://search. emarefa.net/detail/BIM-860363

Chatfield, C. (2005). Durbin-Watson Test, Encyclopedia of Biostatistics. Encyclopedia of Biostatistics. doi: 10.1002/0470011815.b2a12023

Dinov, I., Christou, N., \& Sanchez, J. (2008). Central Limit Theorem: New SOCR Applet and Demonstration Activity. Journal of Statistics Education. 16(2), 215-228. http://www. socr.ucla.edu/htmls/SOCR_Experiments.html.

Income Tax Department. (2019). https://www.istd.gov.jo/ Retrieved March 15, 2019.

Jaradat, M. S. (2013). The effect of self-assessment on the collections of the income and sales tax department from the point of view of the income tax auditors in Jordan. Journal of Accounting and Financial Studies, 8(22), 176-189. https:// search.emarefa.net/detail/BIM-385198

Joudih, I. N. (2016). The Jordanian experience in applying information and communication technology in the tax system. Journal of Industrial Economics, 6(2), 239-266. https://www. asjp.cerist.dz/en/article/19637

Karimi, H., Kimani, E. M., \& Kinyua, J. M. (2017). Effect of technology and information systems on revenue collection by the county government of Embu, Kenya. International Academic Journal of Information Systems and Technology, 2(1), 19-35. http://hdl.handle.net/123456789/1695
Khanfari, F., \&Yazid, A. (2019). The effectiveness of the Algerian tax system in reducing the phenomenon of tax fraud. Journal of Law and Human Sciences, 12(2), 157-178. https://search. emarefa.net/detail/BIM-895693

Kwak, J., \& Park, M. (2020). Effect of auditor's simultaneous audit and tax services and tax-service fee on firm value: Korea's evidence. Journal of Asian Finance, Economics and Business, 7(7), 219-228. https://doi.org/10.13106/jafeb.2020.vol7.no7.219

Luo, B., Groenke, K., Takors, R., Wandrey, C., \& Oldiges, M. (2007). Simultaneous determination of multiple intracellular metabolites in glycolysis, pentose phosphate pathway and tricarboxylic acid cycle by liquid chromatography-mass spectrometry. Journal of Chromatography A, 1147(2), 153-164. https://doi.org/10.1016/j.chroma.2007.02.034.

Monica, F. W., Makokha, E. N., \& Namusonge, G. S. (2017). Effects of electronic tax system on tax collection efficiency in domestic taxes department of Kenya revenue authority. European Journal of Business and Management, 9(17), 51-58. https://www.iiste. org/Journals/index.php/EJBM/article/view/37371

Nguyen, L. T., Nguyen, A. H., Le, H. D., \& Truong, T. V. (2020). The factors affecting corporate income tax non-compliance: A case study in Vietnam. Journal of Asian Finance, Economics and Business, 7(8), 103-115. https://doi.org/10.13106/jafeb.2020. vol7.no8.103

Olatunji, O. C., \& Ayodele, K. B. (2017). Impact of information technology on tax administration in Southwest, Nigeria. Archives of Business Research, 5(9), 139-150. doi. org/10.14738/abr.59.3549

Qaidum, R., \& Twaitiyeh, T. (2019). The Role of the Principles of Tax in Reducing Tax Evasion. Unpublished Master's Thesis, University of Oum El Bouaghi, Oum El Bouaghi, Algeria. http://hdl.handle.net/123456789/8485

Qublan, K. A. (2014). The Effect of Accounting Policies and Procedures Followed in the Income and Sales Tax Department on Reducing Tax Evasion. Unpublished Master Thesis, Amman Arab University, Amman, Jordan. http://thesis.mandumah. com/Record $/ 201430$

Salehi, M., Khazaei, S., \& Tarighi, H. (2019). Tax avoidance and corporate risk: evidence from a market facing economic Sanction country. Journal of Asian Finance, Economics and Business, 6(4), 45-52. https://doi.org/10.13106/jafeb.2019.vol6.no4.45

Sekaran, U., \& Bougie, R. (2013). Research Methods for Business-A Skill Building Approach (6 ${ }^{\text {th }}$ ed.). West Sussex, UK: John Wiley and Sons. https://www.pdfdrive.com/ research-methods-for-business-a-skill-building-approach-6thedition-d8526809.html

Sekaran, U., \& Bougie, R. (2013). Research Methods for Business, Skill-Building Approach (6 ${ }^{\text {th }}$ ed.). Hoboken, NJ: Wiley.

Shaker, A. G. (2017). The role of the electronic tax payment and collection system in developing tax charged procedures - An analytical study at the general tax authority Diwaniyah Branch. Journal of Al-Muthanna Administrative and Economic Sciences, 7(4), 167202. https://www.iasj.net/iasj?func $=$ article\&aId $=134563$. 